\title{
Nutritional value and antioxidant capacity of "cocoa honey" (Theobroma cacao L.)
}

\author{
Elias NASCIMENTO DA SILVA ${ }^{1}$, Danilo da Cruz RAMOS ${ }^{1}$, Lígia Miranda MENEZES ${ }^{1}$, \\ Alexilda OLIVEIRA DE SOUZA ${ }^{1}$, Suzana Caetano da Silva LANNES ${ }^{2}$, Marcondes VIANA DA SILVA ${ }^{1 *}$
}

\begin{abstract}
Cocoa honey is considered as the liquid portion of cocoa pulp that is released from the fruit soon after it is cut open and can be used before fermentation by simple extraction due to its nutritional characteristics. The objective of the present study is to determine the biochemical characteristics of a cocoa by-product, "cocoa honey" $(\mathrm{CH})$, produced in the State of Bahia-Brazil. The biochemical characterization was conducted to determine reducing sugars, total sugars, vitamin C, total dietary fiber, flavonoids, and total antioxidant activity using an $\mathrm{EC}_{50}$. It was observed that cocoa honey can be considered a source of bioactive compounds, can be consumed in natura or processed, and used as an ingredient in the chocolate industry and in other food products. However, it is necessary to use complementary methods, such as HPLC, to quantify the phenolic compounds of this by-product.
\end{abstract}

Keywords: bioactive phytochemicals; cocoa; by-product use; chemical composition.

\section{Introduction}

Cocoa (Theobroma cacao L.) belongs to the Malvaceae family, a species native to South and Central America (Ross, 2001). According to data on the 2009/2010 crops, released by the International Cocoa Organization (International Cocoa Organization, 2011/12), the world's largest cocoa producers are: The Ivory Coast, with 1242 thousand tons, followed by Ghana (632 thousand ton), Indonesia (550 thousand tons), Nigeria (235 thousand tons), Cameroon (209 000 ton), Brazil (161 thousand tons), Ecuador (160 thousand tons), and Papua New Guinea (50 tons). The cultivation of cocoa has always been associated with the production and economic exploitation of its almonds. The quality of the raw material for chocolate production depends on the efficiency of fermentation of cocoa seeds, associated with good manufacturing practices since, at this stage, biochemical transformations in the almonds occur with the release of reducing sugars and aminoacids that, during roasting, will form the precursors of flavor in the final product (Afoakwa et al., 2013).

Just before fermentation, a mucilaginous liquid known as "cocoa honey" is released from the pulp that envelops the cocoa grains. This liquid has a sweet-sour flavor and is rich in sugars and bioactive compounds. The residual material in the seeds, rich in carbohydrates, is a source of substrate for the development of micro-organisms responsible for fermentation, important in the formation of the aromas and flavours of the end product (Efraim et al., 2010; Ouattara et al., 2014).

Due to the cocoa agribusiness crisis that hit Brazil, it has become increasingly necessary to seek alternatives for the full exploitation of cocoa and its derivatives, such as processing the pulp (nectar, jelly, vinegar, liquor) and the shell. This crisis affected especially the Southern part of the State of Bahia, the country's largest cocoa producer; it was caused mainly by a fungus, Moniliophthora perniciosa (Crinipellis perniciosa), the causing agent of a disease known as witches' broom, which almost entirely wiped out the entire cocoa crop (Johns, 1999).

Studies on the physicochemical, biochemical, and microbiological characteristics of "Cocoa honey" $(\mathrm{CH})$ related to its conservation are scarce in the literature, thereby hindering its exploitation and marketing.

Ferreira \& Dias (1982) analyzed the production of "cocoa honey" as an economic activity and concluded that only $0.4 \%$ of the production of this by-product was being used. The authors attributed such reduced percentage of economic use to the lack of knowledge related to conservation, virtually non-existent technological improvement, as well as to the lack of intellectual property registration. However, USP and UESB, 2013 have recently registered a patent application n. PI 102013 005053-9 (Lannes et al., 2013) entitled: Food composition of chocolate and edible icicle containing "Cocoa honey", which highlights the potential for the use of this by-product.

Therefore, the objective of the present study is to define the physicochemical, biochemical and microbiological characteristics of the "cocoa honey" produced in the State of Bahia.

\section{Materials and methods}

The experiment was conducted at the laboratory of the Center for Study in Food Science (NECAL) and at the laboratory of Food Microbiology, both at Southeast Bahia State University (UESB). CH was obtained from healthy and ripe cocoa fruits, 
picked at random. Later, the $\mathrm{CH}$ was packaged in sterilized pet bottles and kept at $-18^{\circ} \mathrm{C}$ at the laboratory until the beginning of the tests. Fresh and freeze-dried samples were used in the analyses. The cocoa fruits were donated by producers from three different farms in the rural area of the city of Ilhéus - Bahia, in the year 2011. The farms are located on the Pontal - Buerarema highway, $20 \mathrm{~km}$ from the downtown area of Ilhéus, at latitude $14^{\circ} 56^{\prime} 50^{\prime \prime} \mathrm{S}$ and longitude $39^{\circ} 18^{\prime} 16^{\prime \prime}$ ' W featuring a tropical wet climate with annual rainfall averages between $2000 \mathrm{~mm}$ and $2400 \mathrm{~mm}$ and average temperature oscillating between 20 and $25^{\circ} \mathrm{C}$.

\subsection{Color}

Color was assessed (wet basis) using the CIELAB, a threedimensional system proposed by the Commission Internationale

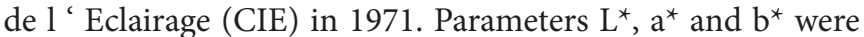
determined using a Colour Quest XE colorimeter (Hunter Lab, United States), in which $\mathrm{L}^{*}$ corresponds to brightness ( $\mathrm{L}^{*}=0$ black and $\mathrm{L}^{*}=100$ white), $\mathrm{a}^{*}$ and $\mathrm{b}^{*}$ correspond to chromaticity $\left(+\mathrm{a}^{*}\right.$ red, $-\mathrm{a}^{*}$ green, $+\mathrm{b}^{*}$ yellow, $-\mathrm{b}^{*}$ blue), and $\mathrm{dEX}^{\star}$, which represents an absolute number that indicates the difference in absolute sensation of color including brightness, hue, and saturation, since the slightest variation.

\subsection{Determination of sugars (reducing, total, and non- reducing sugars)}

Reducing sugars were determined by the dinitrosalicylic acid method (DNS), proposed by (Miller, 1959). The test is based on the reduction of 3,5-dinitrosalicylic acid (yellow color) to a red tinge compound, namely 3-amino-5-nitrosalicylic acid, through the oxidation of reducing monosaccharides in alkaline medium and quantified by spectrophotometry at $540 \mathrm{~nm}$ using glucose as the analytic standard. For determination of total sugars, the method adapted by Matissek et al. (1998), with the addition of $\mathrm{HCl}$ to the sample under heating to hydrolyze the non-reducing sugars, was used. Thereafter, the mixture was neutralized with $\mathrm{NaOH}(30 \%)$ and finally cooled to room temperature in an ice bath. An analogous reading was then taken to determine the reducing sugars. Total sugars were determined by the sum of the concentrations of reducing and non-reducing sugars. Results were expressed as mg of glucose. $100 \mathrm{~g}^{-1}$ fresh weight.

\subsection{Determination of total flavonoids}

Flavonoids were extracted according to the procedure proposed by Nogata et al. (1994) and determination was performed using the procedure proposed by Woisky \& Salatino (1998) with aluminium chloride as reagent. Absorbance measures were taken at $415 \mathrm{~nm}$, and the results were expressed in $\mathrm{mg} .100 \mathrm{~g}^{-1}$ of quercetin dry weight.

\subsection{Determination of vitamin C}

Ascorbic acid content was determined by the titrimetric method with 2,6-dichlorophenol-indophenol sodium (DPI) (Association of Official Analytical Chemistry, 2010) and by replacing the solution of metaphosphoric acid with oxalic acid solution. The method is based on reducing the blue DPI reagent to a colorless coupond by ascorbic acid. When all ascorbic acid is oxidized, the excess DPI makes the solution to change to pink (translucent), indicating the end of the titration process. Results are expressed as mg. $100 \mathrm{~mL}^{-1}$ of ascorbic acid fresh weight.

\subsection{Determination of total phenolics}

For the determination of total phenolic compounds, the procedure proposed by Wettasinghe \& Shahidi (1999) with the Folin-Ciocauteau reagent was used. The total content of phenolic compounds was determined at $725 \mathrm{~nm}$ using a Shimadzu spectrophotometer (UV-Mini 1240). To obtain the linear analytic curves, a stock solution at a concentration of $1 \mathrm{mg}$. $\mathrm{mL}^{-1}$ with a subsequent sequential dilution was used varying the concentration of the stock solution from 0.2 to $1.0 \mathrm{mg}$ of Gallic acid. $\mathrm{mL}^{-1}$ equivalent. The total phenolic compounds in the obtained extracts were expressed as mg of gallic acid equivalent. $100 \mathrm{~g}^{-1}$ of dehydrated sample.

\subsection{Determination of dietary fiber}

The determination of the levels of total dietary fiber (TDF) and insoluble dietary fiber (IDF) of lyophilized cocoa syrup (dry base and wet base) was carried out according to the enzymatic gravimetric method (Prosky et al. 1988; Association of Official Analytical Chemistry, 2010) using a Sigma enzymatic kit (Sigma-Aldrich, United States). Soluble fiber (SDF) was obtained by the difference between TDF and IDF.

\subsection{Determination of antioxidant activity}

The antioxidant activity of the extracts (in dry weight) was determined by the DPPH test, according to BrandWilliams et al. (1995). This method is based on the reduction of the stable radical DPPH (1.1-diphenyl-2-picrylhydrazyl) by the reducing action of the antioxidants present in the sample. The reaction mixture was composed of $3.0 \mathrm{~mL}$ of $0.06 \mathrm{mM} \mathrm{DPPH}$ solution. Ethilc alcohol was used as a blank solution to calibrate the spectrophotometer. The values of effective concentration $\left(\mathrm{EC}_{50}\right)$ in dry weight, which represents the concentration of the sample necessary to sequester $50 \%$ of DPPH radicals, were calculated by plotting the percentage of remaining DPPH $(50 \%)$ as a function of the concentration of the extracts of each sample. The DPPH concentration in the reaction was calculated using the linear analytic curves. After the addition of the DPPH radical, solutions of different concentrations were left to rest, and the decrease in absorbance was recorded at $517 \mathrm{~nm}$ on a spectrophotometer (Shimadzu UV mini 1240, Japan) for one hour with 10-minute intervals between each reading.

\subsection{Microbiological analyses}

The method of direct plating on a potato dextrose agar medium with $10 \%$ tartaric acid, described by Silva et al. (2001) and available in the Handbook of Microbiological Food Analysis methods, was used for the count of yeast and mould. 
Fresh samples were diluted in peptone water at concentrations of $10^{-1}, 10^{-2}$ and $10^{-3}$. Plates were incubated at $22^{\circ} \mathrm{C}$ for 5 days and readings were expressed as UFC.mL ${ }^{-1}$. Most probable number $\left(\mathrm{MPN} \mathrm{g}^{-1}\right)$ of total coliforms was determined using the traditional multiple tube method (Silva et al., 2001), available in the Handbook of Microbiological Food Analysis methods. This method can be employed as a standard since it is widely recommended by the Health Department and other regulatory agencies.

\section{Results and discussion}

Table 1 shows the results of the dietary fiber analysis; it was possible to estimate the total structural components of fiber (cellulose, hemicellulose, lignin, and pectin). The Protocol is based on the determination of the weight of the residue resulting from the elimination of starch and protein through enzymatic hydrolysis by alpha-amylase, protease, and amyloglucosidase), followed by precipitation of soluble dietary fiber into ethanol.

The presence of this food component is of great interest to human health. A number of studies which confirm the role of dietary fiber in preventing certain diseases such as diverticulitis, colon cancer, obesity, cardiovascular problems and diabetes have been reported (Elleuch, et al. 2011). The Brazilian legislation (Brasil, 2008) establishes that dietary fibers have functional claims, provided that they supply at least $1.5 \mathrm{~g}$ of fiber (liquid food).

The dietary fiber content of "cocoa honey" was greater than the minimum amount established by ANVISA per serving of $200 \mathrm{~mL}$ (Brasil, 2003). Thus, it can be considered as a liquid food with functional claims that can help the bowel functions when combined with a balanced diet and healthy habits.

The results of the biochemical characterization are presented in Table 2. Concentrations of reducing sugars were lower than those found by Penha \& Matta (1998), who evaluated fresh cocoa pulp. The authors found levels of 3.7 g. $100^{-1}$ for glucose and $7.4 \mathrm{~g} \cdot 100^{-1}$ for total sugars. This variation can be attributed to the reduced amount of non-soluble dietary fibers $(0.06 \%)$ of cocoa honey.

Table 1. Mean values (\%) of dietary fiber of "cocoa honey"

\begin{tabular}{lcc}
\hline \multicolumn{1}{c}{$\begin{array}{c}\text { Components } \\
\left(\mathrm{g} .100 \mathrm{~g}^{-1}\right)\end{array}$} & Fresh Weight Base & Dry Weight \\
\hline Insoluble fiber & $0.06 \pm 0.01$ & $0.35 \pm 0.06$ \\
Soluble fiber & $1.35 \pm 0.11$ & $8.04 \pm 0.69$ \\
Total Dietary Fiber & $1.41 \pm 0.11$ & $8.47 \pm 0.68$ \\
\hline${ }^{*}$ Results are expressed as mean \pm standard deviation $(\mathrm{n}+3)$. &
\end{tabular}

Table 2. Biochemical characterization of "cocoa honey"*.

\begin{tabular}{lr}
\hline \multicolumn{1}{c}{ Components } & \multicolumn{1}{c}{ Results } \\
\hline Reducing sugar g.100mL & $1.20 \pm 0.50$ \\
Total sugar g.100mL & $2.90 \pm 0.50$ \\
Non-reducing sugar in sucrose g.100 $\mathrm{mL}^{-1}$ & $1.70 \pm 0.50$ \\
Total flavonoids $\mu$ g. $\mathrm{mL}^{-1}$ & $7.19 \pm 0.01$ \\
Vitamin C mg.100mL & $10.90 \pm 0.15$ \\
\hline
\end{tabular}

${ }^{\star}$ Results are recorded as average \pm standard deviation $(n+3)$.
Total flavonoid levels were similar to those observed for most beverages and juices analyzed by Hertog et al. (1992), who found 4-16 mg. $\mathrm{ml}^{-1}$ for red wine, $7 \mathrm{mg} \cdot \mathrm{ml}^{-1}$ for lemon juice, and $3 \mathrm{mg} \cdot \mathrm{ml}^{-1}$ for tomato juice; therefore, cocoa honey can be considered a source of bioactive compounds derived from plants.

Vitamin C levels were higher than those reported by Penha \& Matta (1998) for fresh cocoa pulp (3.9 mg.100 ml-1 of vitamin C) and lower than those found by Couto \& Canniatti-Brazaca, (2010) in citrus varieties, with values ranging from 21.47 and $84.03 \mathrm{mg}$ Ascorbic acid. $100 \mathrm{~mL}^{-1}$. Chaves et al. (2004) obtained $98.65\left(\mathrm{mg} 100 \mathrm{~g}^{-1}\right)$ in acerola juice. Since the recommended daily intake (RDI) for vitamin $\mathrm{C}$ is $45 \mathrm{mg}$ for adults, cocoa honey can contribute with $24 \%$ (RDI) of vitamin C, with the ingestion of only $100 \mathrm{~mL}$ a day.

Among the various classes of naturally occurring antioxidants, phenolic compounds have received much attention in recent years, mainly for inhibiting lipid peroxidation and lipoxygenase in vitro (Gómez-Estaca et al. 2014).

Table 3 presents the results of total phenolic levels and antioxidant activity, using different concentrations, and the calculation of $\mathrm{EC}_{50}$ for "cocoa honey".

The results of the determination of total phenolics, expressed as gallic acid equivalent, varied according to the concentration of extracts. All extracts evaluated had high levels of phenolic compounds, ranging from 101.50 to $1200 \mathrm{mg} \mathrm{GAE} .100 \mathrm{~g}^{-1}$. These values are higher than those recorded by Vieira et al. (2011) in pulp of acerola, bacuri, cashew, guava, hog plum, and tamarind, in which the levels ranged from a maximum $\left(449.63 \pm 10.24 \mathrm{mg} .100 \mathrm{~g}^{-1}\right)$ in acerola and a minimum $\left(7.23 \pm 0.08 \mathrm{mg} .100 \mathrm{~g}^{-1}\right)$ in bacuri.

Salvador (2011) quantified phenolic compounds in cocoa seeds and found values of $21.54 \mathrm{mg} \mathrm{GAE} .100 \mathrm{~g}^{-1}$ and $24 \mathrm{mg}$ GAE. $100 \mathrm{~g}^{-1}$, respectively. These results indicate that the high phenolic content of the cocoa fruit is also present in its pulp and not only in its seed.

Antioxidant activity of cocoa honey, expressed as $\mathrm{EC}_{50}$ (DPPH), was 64.74 ug. $\mathrm{mL}^{-1}$. This result was lower than the average content found by Othman et al. (2007), who quantified the antioxidant activity by calculating $\mathrm{EC}_{50}(\mathrm{DPPH})$ in cocoa beans from regions of Malaysia, Ghana, and The Ivory Coast (1.36 mg.mL $\mathrm{m}^{-1}$ ), and they were higher than the values found by

Table 3. Total phenolic compounds, antioxidant activity, and determination of $\mathrm{EC}_{50}$ for "cocoa honey" in dry weight".

\begin{tabular}{|c|c|c|c|c|}
\hline $\begin{array}{c}\text { Extract } \\
\mathrm{mg}\end{array}$ & $\begin{array}{c}\text { TF } \\
\text { mg. GAE } \\
\text { equivalent. } 100 \mathrm{~g}^{-1}\end{array}$ & $\begin{array}{c}\text { AAM } \\
\%\end{array}$ & $\begin{array}{c}\mathrm{EC}_{50} \\
\left(\text { ug.ml } \mathrm{ml}^{-1}\right)\end{array}$ & $\begin{array}{c}\text { DPPH } \\
\text { g extract. } g^{-1}\end{array}$ \\
\hline 20 & $101.50 \pm 0.03$ & 66.80 & \multirow{4}{*}{64.74} & \multirow{4}{*}{6.34} \\
\hline 30 & $132.90 \pm 0.02$ & 74.70 & & \\
\hline 40 & $811.80 \pm 0.02$ & 75.50 & & \\
\hline 50 & $1200.00 \pm 0.07$ & 85.00 & & \\
\hline
\end{tabular}


Table 4. Color parameters of "cocoa honey"*

\begin{tabular}{cc}
\hline Color parameter & Mean \pm standard deviation \\
\hline $\mathrm{L}^{*}$ & $37.70 \pm 0.16$ \\
$\mathrm{a}^{*}$ & $-1.18 \pm 0.02$ \\
$\mathrm{~b}^{*}$ & $-2.74 \pm 0.10$ \\
$\mathrm{dEX}^{*}$ & $37.64 \pm 0.43$ \\
\hline
\end{tabular}

${ }^{\star}$ Results are expressed as mean \pm standard deviation $(n+3)$.

Vieira et al. (2011) in acerola pulp, 1.74 ug. $\mathrm{mL}^{-1}$. It is known that the higher the value of this index, the lower the efficiency of antioxidant activity. This result indicates a high antioxidant activity in the raw material studied, demonstrating the importance of its exploitation as food.

The characterization of cocoa honey color is presented in Table 4. The values of the color coordinates $L^{\star}, a^{\star}$ and $b^{*}$, lightness $\left(\mathrm{L}^{\star}\right)$ were low. The negative value of coordinates $\mathrm{a}^{\star}$ and $\mathrm{b}^{*}$ close to 0 (zero) indicates that the color of the raw material was close to opaque yellow, indicating a characteristic color of this product; which represents an absolute number that indicates the difference in absolute sensation of color including brightness, hue, and saturation, since the slightest variation since the slightest variation of colour needed for detection by the human eye is equal to 2.0 (Choi et al., 2002). Therefore, this parameter can be used to detect variations in the color of cocoa honey caused by enzymatic and non-enzymatic reactions during processing and storage time.

The result of yeasts and mould counts after 5 days of incubation was $7 \times 10^{2} \mathrm{UFC}^{-1} \mathrm{~g}^{-1}$ This value is lower than that required by the Brazilian Department of Agriculture as set forth by the Technical Regulation for Identity and quality Standards for fruit pulp in natura, according to which, the maximum value was set as $5 \times 10^{3}$ UFC.g $^{-1}$ (Brasil, 2000). All samples analyzed indicated absence of total coliforms, which can be attributed to the high acidity of the product, which disfavors bacterial growth. The results indicate that the "cocoa honey" evaluated in the present study has good microbiological quality and can be consumed safely.

\section{Conclusion}

According to the results obtained, cocoa honey has a high content of reducing sugar and a significant amount of dietary fiber, and it can be considered a natural source of bioactive phenolic compounds with considerable antioxidant activity. Furthermore, it shows a great potential for technological applications in the food industry, so far underexploited.

\section{Acknowledgements}

The authors wish to thank the Southeast Bahia State University for the logistical support and the cocoa farmers for providing the samples used.

\section{References}

Afoakwa, E. O., Quao, J., Takrama, J., Budu, A. S., \& Saalia, F. K. (2013). Chemical composition and physical quality characteristics of Ghanaian cocoa beans as affected by pulp pre-conditioning and fermentation. Journal of Food Science and Technology, 50(6), 1097-1105. http://dx.doi.org/10.1007/s13197-011-0446-5. PMid:24426021

Association of Official Analytical Chemistry - AOAC. (2010). Official Methods of Analysis of the Association of Official Analytical Chemists. 18 th ed. Gaithersburg.

Brand-Williams, W., Cuvelier, M. E., \& Berset, C. L. W. T. (1995). Use of a free radical method to evaluate antioxidant activity. $L W T$ - Food Science and Technology, 28(1), 25-30. http://dx.doi.org/10.1016/ S0023-6438(95)80008-5.

Brasil, Ministério da Agricultura do Abastecimento. (2000). Regulamento técnico geral para fixação dos padrões de identidade e qualidade para polpa de fruta. (Instrução Normativa n. 01/00, de 07 de janeiro de 2000). Diário Oficial da República Federativa do Brasil.

Brasil, Ministério da Saúde, Agência Nacional de Vigilância Sanitária. (2003). Aprova regulamento técnico de porções de alimentos embalados para fins de rotulagem nutricional. (RDC n. 359, de 23 de dezembro de 2003). Diário Oficial da República Federativa do Brasil.

Brasil, Ministério da Saúde, Agência Nacional de Vigilância Sanitária. (2008). Alimentos. Comissões e Grupos de Trabalho. Comissão Tecnocientífica de Assessoramento em Alimentos Funcionais e Novos Alimentos. Alimentos com Alegações de Propriedades Funcionais e ou de Saúde, Novos Alimentos/ Ingredientes, Substâncias Bioativas e Probiótios. Brasília. Retrieved from: http://www.anvisa.gov.br/ alimentos/comissões/tecno_lista_alega.htm

Chaves, M. D. C. V., Gouveia, J. P. G., Almeida, F. A. C., Leite, J. C. A., \& Silva, F. D. (2004). Caracterização físico-química do suco da acerola. Revista de Biologia e Ciências da Terra, 4(2), 1-10.

Choi, M. H., Kim, G. H., Lee, H. S. (2002). Effects of ascorbic acid retention on juice color and pigment stability in blood orange (Citrus sinensis) juice during refrigerated storage. Food Research International, 35(8), 753-759.

Couto, M. A. L., \& Canniatti-Brazaca, S. G. (2010). Quantificação de vitamina $\mathrm{C}$ e capacidade antioxidante de variedades cítricas. Ciência e Tecnologia de Alimentos, 30(1), 15-19. http://dx.doi.org/10.1590/ S0101-20612010000500003.

Efraim, P., Pezoa-García, N. H., Jardim, D. C. P., Nishikawa, A., Haddad, R., \& Eberlin, M. N. (2010). Influência da fermentação e secagem de amêndoas de cacau no teor de compostos fenólicos e na aceitação sensorial. Ciência e Tecnologia de Alimentos, 30(1), 142-150. http:// dx.doi.org/10.1590/S0101-20612010000500022.

Elleuch, M., Bedigian, D., Roiseux, O., Besbes, S., Blecker, C., \& Attia, H. (2011). Dietary fibre and fibre-rich by-products of food processing: Characterisation, technological functionality and commercial applications: A review. Food Chemistry, 124(2), 411-421. http:// dx.doi.org/10.1016/j.foodchem.2010.06.077.

Ferreira, H. I. S., \& Dias, I. L. (1982). Perfil econômico e social da produção de mel de cacau (Boletim Técnico, 97). Ilhéus: Centro de Pesquisas do Cacau.

Gómez-Estaca, J., Lopez-de-Dicastillo, C., Hernandez-Munoz, P., Catala, R., \& Gavara, R. (2014). Advances in antioxidant active food packaging. Trends in Food Science \& Technology, 35(1), 42-51. http://dx.doi.org/10.1016/j.tifs.2013.10.008.

Hertog, M. G. L., Hollman, P. C. H., \& Katan, M. B. (1992). Content of potentially anticarcinogenic flavonoids of 28 vegetables and 9 fruits commonly consumed in the Netherlands. Journal of Agricultural and Food Chemistry, 40(12), 2379-2383. http://dx.doi.org/10.1021/ jf00024a011.

International Cocoa Organization - ICCO. (2011/12). Quarterly Bulletin of Cocoa Statistics (Vol. XXXVIII). London. Retrieved from: 
http://www.icco.org/about-us/international-cocoaagreements/ cat_view/30-related-documents/46-statistics-production.html

Johns, N. D. (1999). Conservation in Brazil's chocolate forest: The unlikely persistence of the traditional cocoa Agroecosystem. Environmental Management, 23(1), 31-47. http://dx.doi.org/10.1007/ s002679900166. PMid:9817770

Lannes, S. C. S., Silva, M. V., Silva, E. N., Ramos, D. C., \& Su, F. (2013). BR n. PI 102013 005053-9. Composições alimentícias de chocolate e de gelado comestível contendo "mel de cacau". São Paulo: Departamento de Tecnologia Bioquímico-Farmacêutica, Universidade de São Paulo; Itapetinga: Departamento de Ciências Exatas e Naturais, UESB.

Matissek, R., Steiner, G., \& Schnepel, F. M. (1998). Análisis de los alimentos: fundamentos, métodos, aplicaciones. Acribia.

Miller, G. L. (1959). Use of dinitrosalicylic acid reagent for determination of reducing sugar. Analytical Chemistry, 31(3), 426-428.

Nogata, Y., Ohta, H., Yoza, K. I., Berhow, M., \& Hasegawa, S. (1994). High-performance liquid chromatographic determination of naturally occurring flavonoids in Citrus with a photodiode-array detector. Journal of Chromatography: A, 667(1-2), 59-66. http:// dx.doi.org/10.1016/0021-9673(94)89051-X. PMid:7952015

Othman, A., Ismail, A., Abdul Ghani, N. A., \& Adenan, I. (2007). Antioxidant capacity and phenolic content of cocoa beans. Food Chemistry, 100(4), 1523-1530. http://dx.doi.org/10.1016/j. foodchem.2005.12.021.

Ouattara, D. H., Ouattara, H. G., Goualie, B. G., Kouame, L. M., \& Niamke, S. L. (2014). Biochemical and functional properties of lactic acid bacteria isolated from Ivorian cocoa fermenting beans. Journal of Applied Biosciences, 77, 6489-6499.

Penha, E. M., \& Matta, V. M. (1998). Características físico-químicas e microbiológicas da polpa de cacau. Pesquisa Agropecuaria Brasileira, 33(11), 1945-1949.

Prosky, L., Asp, N. G., Schweizer, T. F., DeVries, J. W., \& Furda, I. (1988). Determination of insoluble, soluble, and total dietary fiber in foods and food products: interlaboratory study. Journal - Association of Official Analytical Chemists, 71(5), 1017-1023. PMid:2853153.

Ross, J. (2001). Cocoa and chocolate as functinal foods. Natural Health Products Techenology Cluster. Retrieved from: http://www. uoguelph.ca/nhptc/nhpinfoa.html

Salvador, I. (2011). Atividade antioxidante e teor de resveratrol em cacau, chocolates, achocolatados em pó e bebidas lácteas achocolatadas. Tese de Doutorado. Universidade de São Paulo.

Silva, N., Junqueira, V. C. A., \& Silveira, N. F. A. (2001). Manual de métodos de análise microbiológica de alimentos. Varela.

Vieira, L. M., Sousa, M. S. B., Mancini-Filho, J., \& Lima, A. (2011). Fenólicos totais e capacidade antioxidante in vitro de polpas de frutos tropicais. Revista Brasileira de Fruticultura, 33(3), 888-897. http://dx.doi.org/10.1590/S0100-29452011005000099.

Wettasinghe, M., \& Shahidi, F. (1999). Evening primrose meal: a source of natural antioxidants and scavenger of hydrogen peroxide and oxygen-derived free radicals. Journal of Agricultural and Food Chemistry, 47(5), 1801-1812. http://dx.doi.org/10.1021/jf9810416. PMid:10552455

Woisky, R. G., \& Salatino, A. (1998). Analysis of propolis: some parameters and procedures for chemical qualitycontrol. Journal of Apicultural Research, 37(2), 99-105. 